\section{Kontestasi Relawan Teman Ahok Dalam Pemilihan Kepala Daerah DKI Jakarta 2017}

\author{
Bambang Arianto \\ Lembaga Penelitian dan Pengabdian \\ Masyarakat, \\ Universitas Nahdlatul Ulama (UNU) \\ Yogyakarta \\ Korespodensi Penulis. E-mail: \\ ariantobambang@unu-jogja.ac.id
}

\begin{abstract}
Abstrak
Artikel ini menjelaskan kontestasi relawan Teman Ahok dalam kontestasi demokrasi lokal DKI Jakarta 2017. Dalam penelitian ini dinyatakan bahwa kemunculan relawan Teman Ahok didasari oleh kejenuhan publik terhadap proses rekruitmen politik dalam partai politik. Rekruitmen ini disinyalir sarat dengan praktik mahar politik. Kehadiran relawan Teman Ahok ternyata dapat mendorong partisipasi publik dengan dibuktikan tercapainya pengumpulan satu juta kartu tanda pengenal sebagai prasyarat calon independen. Gejala ini menegaskan besarnya perhatian publik terhadap relawan elektoral seperti Teman Ahok. Sekaligus penanda menurunnya kepercayaan publik dan warganet terhadap partai politik. Terutama pada kegagalan partai politik dalam proses rekruitmen politik guna melahirkan kandidat politik pilihan rakyat. Artikel ini berpendapat bahwa kehadiran relawan Teman Ahok dapat menjadi saluran substitusi baru serta otokritik terhadap eksistensi partai politik. Artikel ini juga berpendapat bahwa
\end{abstract}

sekolah partai dapat menjadi salah satu alternatif memperbaiki proses rekrutmen dalam langgam partai politik di Indonesia.

Kata kunci: Relawan Teman Ahok; Partai Politik; Kandidat Politik; Sekolah Partai

\section{Abstract}

This article explains the contestation of Teman Ahok volunteers in the DKI Jakarta local democracy contest in 2017. In this study it was stated that Teman Ahok volunteers were based on public boredom towards the political recruitment process in political parties. This recruitment was allegedly loaded with political dowry practices. The presence of Teman Ahok volunteers turned out to be able to encourage public participation by proven achievement of collecting one million ID cards as a prerequisite for independent candidates. This phenomenon confirms the magnitude of public attention towards electoral volunteers such as Teman Ahok. As well as marking the decline in public and citizen confidence in political parties. Especially in the failure of political parties in the political recruitment process to give birth to the people's chosen political candidates. This article argues that the presence of Teman Ahok volunteers can be a new channel of substitution and self-criticism of the existence of political parties. This article also argues that party schools can be an alternative to improve the recruitment process in political party styles in Indonesia.

Keywords: Teman Ahok Volunteers; Political Parties; Political Candidates; Party School 


\section{A. PENDAHULUAN}

Tahapan kontestasi pemilihan kepala daerah (Pilkada) serentak 2017 DKI Jakarta kian semarak. Hal itu ditandai dengan munculnya komunitas anak muda yang menamakan relawan Teman Ahok. Komunitas ini kemudian berperan sebagai tim sukses pasangan Basuki Thajaja Purnama (Ahok) yang kemudian dapat dikategorikan sebagai relawan elektoral yang bertindak sebagai tim sukses baik di luar jaringan (offline) maupun dalam jaringan (online) terutama di media sosial. Jika ditelisik relawan Teman Ahok lebih banyak beranggotakan para generasi milenial yang mayoritas adalah generasi Y. Kehadiran relawan ini pada awalnya lebih berdasarkan kekecewaaan kepada partai politik yang masih menyisahkan tradisi mahar politik dalam setiap rekruitmen politik. Padahal, generasi milenial yang merupakan populasi terbesar warganet memiliki karakter yang berbeda dalam memaknai politik.

Mengutip studi Jati WR (2015) generasi $Y$ (milenial) memang lebih menyukai platform politik yang bebas, tanpa sekat, inklusif, dan juga independen secara afiliasi politik ketimbang melalui partai politik. Gejala ini yang turut mendorong kemunculan fenomena kesukarelawan (voluntarisme) sejak kontestasi Pilkada DKI Jakarta 2012. Hal itu dibenarkan oleh studi Arianto (2014) bahwa fenomena relawan politik yang terjadi dalam langgam politik Indonesia tidak dapat dikategorikan sebagai partisipasi yang dimobilisasi, justru sebaliknya partisipasi para relawan terlahir secara sukarela (otonomi) baik melalui aksi jalanan (offline) maupun dimedia sosial (online).

Dalam konteks Pilkada DKI Jakarta 2017, partisipasi sukarela ini yang kemudian ditunjukan dengan keberhasilan relawan Teman Ahok dalam mendorong publik untuk ikut aktif mengalang dukungan untuk memenuhi prasyarat sebagai calon independen. Salah satu prasyarat tersebut adalah menyumbangkan kartu tanda pengenalnya (KTP) secara sukarela. Hasilnya cukup memuaskan, bahkan jika dikalkulasi perolehan suara beberapa partai dalam pemilu legislatif 2014 di DKI Jakarta justru masih dibawah raihan sejuta KTP yang digalang oleh relawan Teman Ahok. Gejala inilah menegaskan bahwa tengah terjadi ketidakpercayaan publik terhadap partai politik terutama dalam proses rekruitmen politik.

Padahal menurut studi Matthias Caton (2007), fungsi artikulasi, agregasi dan rekruitmen politik dapat memainkan peran fundamental bagi partai dalam mengarungi dinamika politik. Bahkan, menurut studi Pamungkas (2011) fenomena rukruitmen politik dapat menjelaskan banyak 
hal dari dinamika politik; Pertama, dapat menunjukkan lokus dari kekuasaan partai politik yang sesungguhnya. Apakah kekuasaan partai politik bersifat oligarkis atau bersifat menyebar. Kedua, menggambarkan perjuangan kekuasaan internal partai politik. Perjuangan faksi-faksi di dalam partai akan sangat nampak dalam rukruitmen politik. Ketiga, menunjukkan politik representasi yang berusaha dihadirkan oleh partai politik. Keempat, menggambarkan bagaimana sirkulasi elit terjadi. Kelima, menjadi penentu wajah partai diruang publik. Terakhir, rekruitmen politik berada pada posisi sentral dalam mendefinisikan tipe kepartaian. Dikarenakan sebuah partai disebut sebagai partai kartel, catch-all, kader dan massa atau busines-firm dapat dilihat dari bagaimana rekruitmen politik dilakukan. Selain itu studi Norris dalam Katz dan Crotty (2006) bahwa proses rekruitmen politik dimulai dari (1) siapa kandidat yang dapat dinominasikan (candidacy), (2) siapa yang menyeleksi (selectorate), (3) dimana kandidat diseleksi, (4) bagaimana kandidat diputuskan.

Akan tetapi dalam realitasnya partai politik belum juga mampu menerapkan mekanisme rekruitmen politik dengan baik apalagi sistematis. Hal ini yang menyebabkan partai politik seringkali bergerak dengan logika pragmatis hingga akhirnya tidak lagi mengedepankan proses demokratisasi intrapartai dalam proses mencari figur politik pilihan rakyat. Eksesnya partai kemudian terjebak dalam fenomena politik berbiaya tinggi yang dapat melambungkan efek domino atas tiap persoalan sampai pada titik korupsi politik. Apalagi fenomena ini semakin diperparah dengan menguatnya tradisi mahar politik menjelang pemilihan kepala daerah. Bahkan, hingga saat ini tradisi mahar politik terus berkembang dengan istilah baru seperti uang survei pilkada. Yang mana setiap kandidat politik diwajibkan menyetorkan sejumlah uang yang sudah ditetapkan pengurus partai. Alasannya, tentu uang tersebut akan digunakan untuk survei internal dengan tujuan mengetahui elektabilitas kandidat politik yang diusulkan kepada pengurus pusat partai. Bahkan semenjak dibukanya pendaftaran calon kepala daerah saja, praktik permintaan uang survei ini semakin marak di daerah yang akan melaksanakan Pilkada (Asril, 2015). Selain itu ada pula istilah biaya gotong-royong, acara debat atau focus group discussion (FGD) hingga biaya untuk menyewa para ahli kejiwaan yang dibebankan oleh kandidat calon kepala daerah. Itu mengapa, tradisi ini kemudian terungkap ke publik, dengan adanya salah satu kandidat calon bupati Gunungkidul Daerah Istimewa Yogyakarta, yang 
Vol.1 No.1 Juni 2019

menyiapkan gugatan hukum terhadap Partai Gerindra dikarenakan gagal dicalonkan, padahal sang calon telah menyetor mahar politik sebesar 25 juta kepada pengurus Partai Gerindra Gunungkidul.

Identifikasi tersebut, menegaskan bahwa menjelang kontestasi pilkada, dominasi dan arogansi partai politik semakin kian kentara. Hanya dengan dalih strategi pemenangan kontestasi, partai politik berusaha menyandera kandidat politik untuk mengeluarkan mahar politik. Meski terdapat larangan bagi partai untuk menerima mahar politik seperti yang diutarakan pada UU Pilkada Nomor 8 Tahun 2015, tetapi regulasi tersebut tidak menjamin dapat menekan merebaknya tradisi mahar politik. Sebab aturan hukum tetap memberi ruang bagi partai untuk ikut dalam proses rekruitmen politik dalam Pilkada yang termaktub dalam Pasal 56 Ayat (2) Undang-Undang Nomor 32 Tahun 2004 tentang Pemerintahan Daerah, dimana mengatur calon pasangan kepala daerah diajukan oleh partai politik atau gabungan partai politik. Kesempatan inilah yang seringkali digunakan oleh partai politik untuk menjadikan mahar politik sebagai bekal untuk bertahan hidup. Apalagi pembiayaan kampanye akan dibebankan pada anggaran pendapatan dan belanja daerah (APBD). Dengan kata lain, para calon kandidat kepala daerah akan banyak memiliki dana lebih mengingat pembiayaan kampanye menjadi tanggung jawab Komisi Pemilihan Umum Daerah (KPUD). Dampak lainnya dari tradisi mahar politik dapat melahirkan politik plutokrasi, yakni sistem politik yang hanya menempatkan orangorang dengan kekuatan finansial besar yang akan terpilih. Sebab, kandidat bermodal besar akan lebih leluasa menggunakan uangnya untuk mencalonkan diri dalam proses kandidasi hingga bisa membeli suara pemilih (voter). Gejala politik plutokrasi ini pada akhirnya dapat mendorong lahirnya perburuan rente dalam jebakan birokrasi negara dan pemerintahan, yang seringkali melahirkan politisi miskin karakter. Jikalau tradisi mahar politik dalam ritus kontestasi demokrasi lokal seringkali merebak, maka hal itu dapat merusak proses rekruitmen politik.

Eksesnya partai politik cenderung akan meninggalkan identitas ideologi dan gagal fungsi, yang menyebabkan publik semakin merasa ragu dengan eksistensi partai dalam menawarkan kandidat politik dalam Pilkada DKI Jakarta. Keraguan inilah yang menyebabkan sebagian kaum muda tergerak mendirikan relawan elektoral bernama Teman Ahok. Apalagi saat itu tengah terjadi perselisihan antara Basuki Thajaja Purnama dengan para 
legislator di DPRD DKI Jakarta. Perselisihan ini kemudian dikhawatirkan dapat menjadi celah bagi para legislator untuk tidak mendukung Ahok dari jalur partai. Oleh karena itu, para pegiat komunitas Teman Ahok mendirikan komunitas relawan elektoral sebagai saluran substitusi baru selain partai. Tujuannya adalah agar sosok Basuki Thajaja Purnawa tetap dapat maju melalui calon independen. Gejala ini selaras dengan studi yang pernah dilakukan oleh Kurniawan (2011) yang menyatakan bahwa kehadiran calon perseorangan awalnya dianggap menawarkan perubahan sekaligus alternatif memperkaya pilihan, di tengah kejenuhan masyarakat terhadap partai politik yang kian oligarkhis, tertutup, pragmatis dan mengidap sejumlah penyakit lainnya. Studi Kurniawan juga memperjelas posisi calon perseorangan sebagai jalan keluar bagi siapapun yang hendak mencicipi kontestasi Pilkada, namun kesulitan menembus ruang kandidasi yang disediakan partai politik.

Gambaran tersebut menegaskan bahwa kemunculan relawan Teman Ahok dapat menjadi salah satu wahana otokritik bagi kinerja partai yang selama ini masih mengalami kegagalan terutama terkait rekruitmen politik. Oleh sebab itu, momentum kehadiran relawan Teman Ahok dapat menjadi salah satu pijakan guna mengevalusi kinerja partai yang kemudian memunculkan wacana reformasi partai. Reformasi yang dapat dimulai dengan pelembagaan sekolah partai untuk mendorong partai agar dapat kembali mengedepankan proses rekruitmen politik yang sesuai dengan mekanisme pelembagaan parpol.

Pendek kata, dengan adanya perubahan rekonfigurasi kontestasi Pilkada DKI Jakarta 2017 sejak kehadiran relawan Teman Ahok terhadap partai kemudian mengajak kita pada dua pertanyaan; Bagaimana kontestasi relawan Teman Ahok bisa menarik atensi dan partisipasi publik dalam mengusung Basuki Thajaja Purnama? Mengapa partai politik pasca reformasi belum mampu melahirkan kandidat politik pilihan rakyat? Batasan dalam penelitian ini hanya seputar peran dan implikasi relawan Teman Ahok yang kemudian dapat menjadi saluran substitusi baru serta wahana otokritik kinerja partai dalam kontestasi Pilkada DKI Jakarta 2017.

\section{B. TEORI (Literature Review) 1. Profil Relawan Teman Ahok}

Pada awalnya para pendiri relawan Teman Ahok merupakan bekas relawan Jakarta Baru yang didirikan pada 2012. Jakarta Baru merupakan penyokong pasangan Joko Widodo dan Basuki Thajaja Purnama dalam Pemilihan Kepala 
Daerah (Pilkada) DKI Jakarta 2012. Pendiri relawan Teman Ahok berjumlah lima orang, berusia 2325 tahun. Mereka adalah Amalia Ayuningtyas, Singgih Widiyastono, Aditya Yogi Prabowo, Muhammad Fathony, dan Richard Haris Purwasaputra. Sedangkan empat dari pendiri Teman Ahok merupakan relawan Jakarta Baru 2012. Menurut salah satu pendiri relawan Teman Ahok Singgih Widyastomo di Gudang Sarinah, Pancoran, Jakarta Selatan, Minggu (29/5/2016), dua tahun menjabat sebagai Wakil Gubernur DKI Jakarta, Ahok memutuskan untuk keluar dari Partai yang mengusungnya di Pilkada DKI 2012, Gerindra. Ahok merasa kecewa dengan partainya yang mendukung usulan kepala daerah dipilih DPRD. Menurut Ahok, dukungan itu berbeda jauh dari visi misi Gerindra ketika partai itu menariknya dari Partai Golkar. Saat itu Ahok menilai Gerindra sudah tidak lagi sesuai dengan konstitusi semula yang mengutamakan kepentingan rakyat. Karena apabila kepala daerah dipilih oleh DPRD, mereka hanya akan mementingkan anggota dewan dan mengesampingkan urusan rakyat. Ahok resmi keluar dari Gerindra September 2014 dan sudah tidak memiliki kendaraan partai lagi. Keluar dari partai Gerindra, Ahok menggantikan Joko Widodo yang terpilih menjadi presiden pada Pemilihan Umum Presiden 2014.
Disaat itulah Ahok mengungkapkan bahwa ada alokasi anggaran titipan, yang bisa dikategorikan sebagai anggaran siluman, senilai total Rp 12 triliun dalam APBD DKI tahun 2015 yang pada akhirnya membuat gaduh. Kemudian Singgih Widiyastono dan relawan yang tergabung dalam Jakarta Baru melancarkan aksi di Bundaran Hotel Indonesia, Jakarta Pusat, Minggu (1/3/2015). Mereka melakukan aksi Lawan Begal APBD.

Para relawan ini kemudian mendeklarasikan dukungan lawan begal di Car Free Day. Selain itu Singgih Widiyastono juga menceritakan ihwal kedekatan mereka sampai membentuk perkumpulan Teman Ahok. Perkumpulan itu terbentuk dengan legalitas akta notaris pada 16 Juni 2015. Singgih Widiyastono bertugas sebagai juru bicara. Selain itu, Singgih Widiyastono dan Aditya Yogi Prabowo mengurusi pembukaan posko relawan Teman Ahok. Sedangkan Muhammad Fathony bertanggung jawab dalam urusan logistik dan Richard Haris Purwasaputra bertugas dalam hal entridata. Singgih menyatakan para pendiri tidak berkumpul setiap hari di sekretariat Teman Ahok. Sebab, di antaranya ada yang sibuk bekerja dan telah berkeluarga. Misalnya Aditya Yogi Prabowo yang bekerja sebagai sales marketing obat dan Muhammad Fathony yang menjadi pemasok ban. Sedangkan Amalia 
Ayuningtyas, baru saja lulus S-1 di Universitas Indonesia jurusan Fakultas Ilmu Komunikasi dan belum bekerja dan Richard Haris Purwasaputra baru saja lulus dari Universitas Negeri Jakarta.

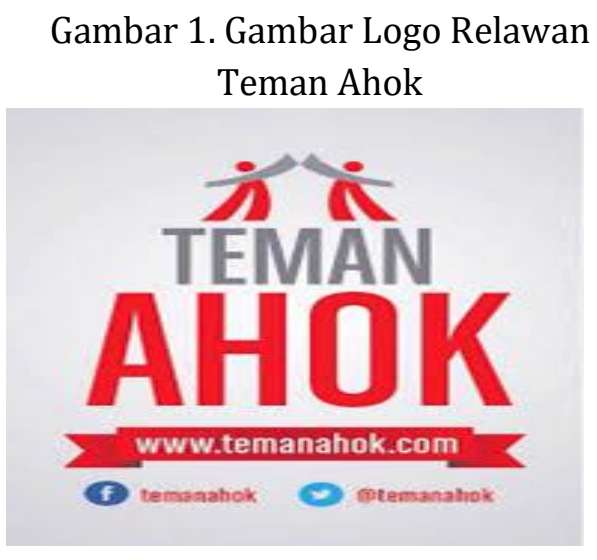

(Sumber: www.temanahok.com)

\section{Relawan Elektoral dan Kandidat Politik}

Dalam sejarah politik Indonesia fenomena relawan elektoral telah dijumpai semenjak pasca reformasi. Meski demikian baru pada kontestasi Pilkada DKI Jakarta 2012 fenomena relawan elektoral dikenal yang kemudian puncaknya terjadi pada kontestasi presidensial 2014. Dalam penelitian ini penulis sengaja membedakan antara relawan elektoral dan relawan politik. Penulis kemudian menempatkan komunitas Teman Ahok sebagai relawan elektoral dikarenakan komunitas ini hadir disaat kontestasi Pilkada DKI Jakarta 2017 berlangsung dan hanya bersifat insidental. Sehingga kita belum bisa menakar apakah pasca pilkada DKI Jakarta 2017 relawan
Teman Ahok akan tetap aktif atau malah mengambil sikap pasif. Hal itu berbeda dengan pengertian relawan politik yang memiliki makna lebih luas, yakni relawan yang tidak hanya hadir disaat kontestasi politik, namun pasca kontestasi tetap aktif sebagai pengawas dan pengawal pemerintahan. Berikut logo dari relawan Teman Ahok dalam Pilkada DKI Jakarta 2017.

Terlepas dari identifikasi relawan elektoral tersebut, menariknya dalam kontestasi pilkada DKI Jakarta 2017 sosok kandidat politik yang berkontestasi---telah banyak menarik hadirnya komunitas relawan dari ketiga pasangan calon. Sebut saja; pasangan Anies Baswedan - Sandiago Uni dengan relawan ABDI Rakyat, Sahabat Sandiago Uno. Kemudian Ahok Djarot dengan Teman Ahok, JASMEV 2017, Muda Mudi Ahok, terakhir pasangan Agus Harimurti - Sylviana Murni dengan relawan Agus Fans Club (AFC). Hadirnya beragam komunitas relawan ini mengonfirmasi bila faktor kandidat politik menjadi daya tarik tersendiri. Hal itu tergambar dari salah satu relawan yang ikut menyumbangkan KTP-nya karena tertarik dengan sosok Basuki Thajaja Purnama. Bagi saya relawan ini sosok Basuki Thajaja Purnama telah terbukti menghasilkan kerja nyata, bersih tidak korupsi dengan ide perencanaan pembangunan DKI 
Jakarta yang lebih sistematis. Hal ini sangat berbeda dengan kandidat politik yang dimiliki oleh parpol yang lebih banyak berwacana tanpa prestasi yang jelas. Hal senada diutarakan warga DKI Jakarta yang tergerak menyumbangkan KTP-nya secara sukarela, alasan utamanya karena sosok Ahok telah banyak memperbaiki sungai, serta fasilitas penunjang lainnya sehingga wajah Jakarta saat ini tampak lebih asri dan nyaman.

Pernyataan warga DKI Jakarta tersebut menegaskan bahwa kandidat politik lebih utama ketimbang parpol yang sekaligus mengonfirmasi bahwa fenomena personalisasi politik dalam langgam politik Indonesia semakin mengakar. Fenomena personalisasi inilah yang kian membuat partai banyak mengalami kehilangan akarnya di hadapan publik, sebab publik lebih tertarik memilih kandidat politik ketimbang partai. Selain itu, hal ini ditandai dengan terjadinya penurunan besar-besaran angka partisanship dari pemilu ke pemilu. Partisanship dalam konteks ini merupakan perasaan kedekatan atau identifikasi terhadap partai tertentu (party ID). Bahkan studi Mujani dan Liddle (2010) menunjukkan, tahun 2004 angka partisanship di Indonesia berada pada kisaran 60 persen. Angka ini terus menurun dan tahun 2009 menjadi hanya sekitar 22 persen.
Gejala atas jatuhnya identitas partai secara signifikan bisa diidentifikasi sebagai bentuk kekecewaan masyarakat terhadap partai politik di Indonesia. Eksesnya terjadi peralihan perhatian publik kepada kandidat politik yang lebih dianggap memiliki representasi gagasan ketimbang partai yang tidak lagi menjadi satu institusi penting guna menyalurkan pilihan politik. Hal ini juga disebabkan dari laku elit partai yang seringkali menempuh cara instan dalam menyemai kandidat politik. Sebut saja ketergantungan partai pada tingkat keterpilihan kandidat politik pada iklan politik dan upaya politik hiperrealitas. Padahal citra yang ditampilkan oleh media hanyalah ilusi hiperrealitas yang justru menyebabkan penumpukan sensibilitas kehidupan sosial karena masyarakat sudah terserap dalam pusaran halusinatif. Dampak dari semua itu, tidak heran bila di setiap daerah pemilihan acapkali kita temui lebih banyak iklan figur politik ketimbang iklan partai. Akhisnya partai seringkali berekspektasi bahwa melalui iklan politik yang gencar dan terus-menerus, aspek personalitas sang figur akan semakin meroket. Itu mengapa banyak kandidat politik kemudian dipasarkan menurut gaya yang tidak berbeda dengan produkproduk dalam nalar konsumerisme dan selebritas. Artinya dalam menggapai popularitas, kandidat 
politik seringkali mengkonstruksi diri dan berevolusi menjadi selebritas, yang kemudian seolaholah terkesan sebagai kandidat politik yang arif, empatik, cerdas, pro-rakyat hingga harus memaksakan diri untuk melakukan blusukan guna menggaet atensi pemilih.

Gejala inilah yang menyebabkan elektabilitas partai akhirnya kalah jauh ketimbang figur politiknya. Akhirnya kandidat politik dinilai lebih penting ketimbang platform apalagi ideologi partai. Itu mengapa kemudian dalam langgam politik Indonesia, justru kandidat politik yang banyak melahirkan dan membesarkan partai politik. Sebut saja, Soekarno melahirkan Partai Nasional Indonesia (PNI), Soeharto membentuk Golkar, Abdurahman Wahid (Gus Dur) melahirkan Partai Kebangkitan Bangsa (PKB), Megawati Soekarnoputri merekonstruksi Partai Demokrasi Indonesia yang kemudian menjadi Partai Demokrasi Indonesia Perjuangan, Surya Paloh membentuk Partai Nasdem, Prabowo Subianto melahirkan Partai Gerakan Indonesia Raya (Gerindra), Susilo Bambang Yudhoyono melahirkan partai Demokrat, Wiranto membentuk Partai Hati Nurani Rakyat (Hanura), serta Harry Tanoe Sudibyo melahirkan partai Perindo.

Sejatinya aspek menyemai personalitas kandidat politik memang diperlukan dalam era demokrasi langsung, sebab kandidat politik harus dikenal luas agar benar-benar tertancap di benak publik. Akan tetapi, aspek personalitas bukanlah segalagalanya. Sebab dalam jangka panjang keawetan sebuah partai politik ditentukan oleh seberapa kuat institusinya bukan seberapa besar pengaruh kandidatnya. Apalagi kita ketahui bahwa kandidat politik bersifat jangka pendek karena terbatas pada durasi waktu. Sejatinya kandidat politik itu penting, namun eksistensi partai jauh lebih penting, sehingga jangan sampai parpol hanya dijadikan sebatas alat pemanis politik. Artinya, upaya menyemai personalisasi tetap diperlukan dalam kancah politik, namun hendaknya harus dengan kadar yang proporsional dan masuk akal. Sebab jika tidak proporsional maka dikhawatirkan upaya menyemai figur politik akan sia-sia. Pasalnya seiring berkembangnya pelembagaan demokrasi digital terutama menguatnya aktivisme digital telah membuat publik semakin rasional dan pasti tidak secara serta merta menerima figur politik yang belum dikenal rekam jejaknya.

Narasi tersebut semakin menegaskan bahwa kandidat politik telah banyak mengubah rekonfigurasi politik di Indonesia. Artinya kultur politik Indonesia masih sangat memiliki ketergantungan terhadap kandidat 
politik. Hal yang sama juga terjadi dalam sejarah relawan elektoral. Yang mana kandidat politik menjadi penentu kelahiran relawan politik bukan ideologi ataupun kepemimpinan. Sebut saja yang terjadi dari relawan elektoral Jogja Independen (Joint) yang mencoba mendorong kelahiran relawan elektoral dengan berbasis ide dan kepemimpinan bukan pada kandidat atau politik. Hasilnya, tidak lama setelah deklarasi relawan Joint Yogyakarta menyatakan membubarkan diri karena tidak memiliki kandidat politik yang layak untuk dijadikan calon walikota Yogyakarta. Berbeda dengan relawan Teman Ahok yang hadir karena berbasiskan ketertarikan terhadap sosok Basuki Thajaja Purnama (Ahok). Berkat sosok Ahok inilah yang kemudian dapat menjadi magnet utama untuk menarik dan melahirkan relawan elektoral. Bahkan bukan hanya Teman Ahok yang berdiri karena dipengaruhi oleh sosok Ahok. Ada banyak pula relawan yang bermunculan termasuk relawan politik digital seperti Jokowi Ahok Social Media Volunteers (JASMEV) 2017. Bahkan relawan JASMEV 2017 untuk Pilkada DKI Jakarta sejak membuka pendaftaran relawan, sudah menggelar tiga kali pelatihan bagaiamana menjadi relawan dan berkampanye positifi di media sosial.

\section{METODE}

Metode Penelitian ini mengunakan pendekatan kualititatif eksplanatoris yang dimulai dari Januari 2016 hingga Januari 2017. Sedangkan objek penelitian merupakan para pegiat relawan Teman Ahok dan beberapa aktivis warganet terutama di Twitter. Penelitian ini mengunakan teknik studi kepustakaan yang digunakan untuk memilih informasi penelitian dan pengumpulan data. Adapun untuk mengukur validitas penelitian, peneliti menggunakan triangulasi sumber dengan membandingkan data hasil pengamatan dan wawancara, keadaan dengan perspektif orang, dan hasil wawancara dengan isi dokumen (Moleong, 2005).

\section{HASIL DAN PEMBAHASAN}

\section{Saluran Substitusi Baru Partai}

Sejatinya partai politik merupakan representasi rakyat yang didirikan oleh elite pendirinya, lengkap dengan tujuan dan simbol-simbol yang ditetapkan, harapannya partai mampu mengagregasi kepentingan rakyat. Alih-alih mengagregasi kepentingan rakyat, ironisnya justru semakin banyak jumlah partai di Indonesia semakin banyak pula persoalan yang ditampilkan oleh partai. Artinya, semakin banyak partai bukan berarti pilihan rakyat semakin beragam. Justru, antara satu partai 
dengan yang lain memiliki ciri, karakter simbolik dan ideologis yang sama. Hal inilah yang kemudian menimbulkan tingkat persaingan yang ketat antar partai. Gejala inilah yang menyebabkan partai berebut mencari sosok kandidat pendulang vote getter, terutama dari kalangan pesohor dengan mengesampaingkan proses rekruitmen politik yang mengedepankan mekanisme meritokrasi.

Akibatnya partai politik seringkali berupaya mendongkrak popularitas kandidat politik yang semakin irasional ketimbang rasional. Padahal popularitas kandidat politik belum tentu linier dengan elektabilitas. Banyak kandidat politik yang memiliki popularitas tinggi tetapi justru memiliki elektabilitas dan rekam jejak yang sangat minim. Artinya langkah taktis partai untuk terus mengejar vote getter dengan hanya menghandalkan popularitas menyebabkan partai sudah tidak lagi dianggap sebagai penyambung lidah amanat rakyat, melainkan lembaga politik yang sektoral, segmentatif dan egoistis. Akhirnya kegagalan demi kegagalan partai dalam pelembagaan internal partai terutama kandidasi politik, menyulut gelombang menurunnya kepercayaan publik terhadap institusi ini.

Jadi tidak heran bila dalam kontestasi Pilkada DKI Jakarta 2017 sejumlah anak muda yang tergabung dalam komunitas
Teman Ahok dan kecewa dengan kinerja partai kemudian berusaha mencari saluran substitusi baru partai melalui jalur independen guna mengusung figur politik pilihannya. Dari sinilah terbentuk relawan Teman Ahok yang menggalang dukungan terutama dari media sosial (online) guna mengusung Basuki Thajaja Purnama maju lewat jalur independen. Dukungan ini kemudian berlanjut dengan kerjakerja teritorial yang dilakukan Teman Ahok dalam upaya pengumpulan sejuta kartu tanda pengenal. Bahkan hingga batas waktu yang ditetapkan relawan Teman Ahok berhasil meraup 1.000.264 juta kartu tanda pengenal. Pencapaian kinerja yang sangat luar biasa ini tentulah didukung oleh peran media sosial yang begitu masif dalam menarik perhatian dan atensi netizen. Selain itupula banyak pendukung dari pasangan Basuki Thajaja Purnama yang menjadi buzzer dan influencer dengan folower ribuan. Dalam langgam politik digital istilah buzzer politik merupakan sebuah aktivitas pemasaran politik yang berisi informasi pada saluran komunikasi digital untuk menciptakan efek mempengaruhi dan menjadi perbincangan luas (viral) hingga kemudian menjadi opini publik. Tujuannya agar dapat memberikan efek mempengaruhi dan dapat menjadi perbincangan luas (viral) dalam langgam politik digital. Untuk menciptakan efek 
mempengaruhi tentulah harus di sertai oleh konten kreatif, seperti video, disain grafis, meme dan aplikasi game.

Seringkali Buzzer politik melakukan kampanye politik dengan melempar opini, informasi dan postingan melalui Twitter, Facebook, Instagram dan Youtube. Selain buzzer kita juga mengenal istilah influencer merupakan sosok buzzer yang dapat mempengaruhi follower-nya sehingga kemudian dapat memberikan efek buzz bersama-sama di sosial media. Hal ini disebabkan karakter influencer biasanya merupakan sosok yang memiliki kreativitas dan inovasi yang berbeda dengan yang lain dalam mengunggah postingan hingga memberikan efek mempengaruhi bagi netizen lainnya untuk bertindak sama dengan nalarnya. Para buzzer politik dan influencer inilah yang kemudian seringkali mempengaruhi opini publik hingga kemudian melahirkan banyak dukungan yang dapat tergambar dari beragam trending topic. Sehingga upaya dan langkah taktis untuk pengalangan dukungan sejuta tanda pengenal cukup masif yang di ikuti oleh tagar \#KTP Gue untuk Ahok. Berikut salah satu meme yang digunakan Teman Ahok dalam mengalang dukungan pengumpulan sejuta KTP.

Gambar 2. salah satu meme yang digunakan Teman Ahok

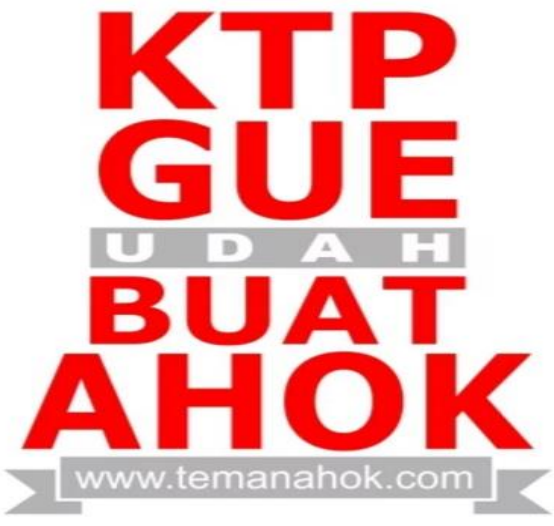

Sumber : www.temanahok.com

Gejala ini semakin menegaskan bahwa penggunaan media sosial dalam setiap kontestasi politik baik lokal maupun nasional memegang peran penting. Media sosial kemudian terbukti dapat memunculkan berbagai terobosan bagi publik untuk dapat saling berinteraksi tanpa batas hingga menggalang dukungan terkait agenda politik dan pemerintahan. Hal itu disebabkan media sosial memiliki karakter partisipatoris, murah, cepat dan non-hierarki yang kemudian dapat mengikis sikap apati politik publik. Bahkan, lewat media sosial publik dapat menggalang dukungan untuk memperjuangkan isu spesifik dalam masyarakat yang kemudian diafirmasi dan dipenuhi oleh negara. Sebut saja melalui gerakan tagar (hash tag) pesan di media sosial. Dengan kehadiran beragam tagar yang menjadi trending topic inilah kita dapat melihat gambaran opini publik yang tengah berkembang. Itu mengapa trending topic menjadi Dikatakan demikian 
karena peran trending topik saban hari memiliki daya magis yang kuat dalam mempengaruhi nalar warganet. Ironisnya, simbolisasi informasi dan pengetahuan yang seringkali ditandai oleh trending topik, acapkali digunakan untuk membalikan fakta dan opini publik sesuai kepentingan kelompok masing-masing. Akibatnya banyak isu-isu sensasional yang awalnya merupakan kebenaran kemudian berbalik menjadi sebuah kebohongan hingga ujaran kebencian karena mudahnya memanipulasi trending topik. Jadi, tidak heran bila kemudian dalam jagat digital akan tersedia informasi asli dan informasi palsu yang hadir secara bersamaan.

Mengutip studi Jati WR (2015) demokrasi jadi hidup di era sekarang karena keberadaan informasi dan teknologi yang cepat. Bahkan masyarakat telah berkembang menjadi masyarakat informan yang menerapkan nilai demokrasi secara praksis, seperti tarnsparansi, partisipasi, representasi dan akuntabilitas. Keempat hal itulah yang menjadi inti demokrasi digital yang kini mewabah di kalangan kelas menengah kita hari ini. Kecenderungan dari keempat nilai demokrasi digital tersebut menyeruak dan mengentak di ruang publik karena dibukanya keran interaksi dan diskusi kritis yang melebar, baik di level online maupun offline. Jadi, di era digital pengaruh kaum intelektual untuk mendorong partisipasi publik semakin terbuka lebar dan kuat. Jadi tidak heran bila kemudian publik kian jenuh dan beralih kepada komunitas relawan elektoral dalam menyalurkan aspirasinya terutama perihal estafet kepemimpinan politik di DKI Jakarta. Keinginan itu semakin menguat semenjak sosok Basuki Thajaja Purnama menjelaskan alasan untuk memilih jalur independen. Bahkan menurut Basuki Tjahaja Purnama calon independen tidak akan pernah ada jikalau partai politik bisa melahirkan calon pemimpin secara profesional. Pasalnya hingga saat ini kebanyakan parpol yang ada di Indonesia belum menerapkan sistem yang profesional dalam melahirkan calon pemimpin. Hal ini disebabkan dominasi oleh para elit dan petinggi partai. Artinya ungkapan Basuki Thajaja Purnama tersebut menegaskan bahwa arogansi elit partai menyebabkan publik beralih mencari saluran substitusi baru guna menyalurkan aspirasinya.

\begin{tabular}{lrr}
\multicolumn{2}{c}{ Tingginya } & antusiasme \\
publik & menjadikan & relawan \\
elektoral & sebagai & saluran
\end{tabular}
substitusi baru partai lebih banyak disebabkan oleh beberapa faktor diantaranya; Pertama, tengah terjadi penurunan kepercayaan publik terhadap parpol sebagai salah satu institusi demokrasi maupun saluran partisipatoris publik. Hal itu disebabkan, laku sebagian elit partai yang kerap 
mengartikan politik sebagai persoalan personal ketimbang persoalan organisasi. Akibatnya, partai sudah tidak lagi berpikir soal pengorganisasian ide dan pergulatan di bawah haluan ideologi tertentu. Tetapi lebih cenderung berpikir soal bagaimana merebut figur populer untuk mendongkrak dukungan kolektif publik. Partai akhirnya sangat susah menjadi rahim ideologis bagi calon-calon pemimpin. Sengkarut wajah partai inilah yang kemudian menjadi penyebab utama terputusnya fungsi linkage antara parpol dan publik. Kedua, kehadiran relawan elektoral mengonfirmasi semakin menguatnya partisipasi publik dalam upaya pelembagaan demokrasi. Hal itu ditandai oleh semakin terbukanya akses publik untuk maju dalam kontestasi politik. Serpihan-serpihan ini pada akhirnya melahirkan gerakan non partisan yang mampu menumbangkan oligarkis partai dalam kontestasi politik Indonesia. Ketiga, relawan elektoral memiliki jangkauan segmentasi pemilih lebih luas, karena tidak terikat oleh ideologi parpol apapun. Bahkan dalam nalar pemilih pemula yang belum memahami politik secara komprehesif, tentulah lebih mudah berdialog dengan relawan ketimbang aktivis maupun kader partai politik. Hal itu tentunya berbeda jika dibandingkan dengan parpol, yang sangat sulit bergerak menembus langsung pada pemilih.
Karena dibatasi sekat-sekat ideologis atau buruknya citra elite parpol sehingga sulit menarik atensi pemilih.

Salah satu fakta nyata bila relawan elektoral sebagai saluran substitusi baru dapat dilihat dari tumbuhnya partisipasi publik yang dimanifestasikan dalam bentuk pengumpulan sejuta tanda pengenal (KTP). Bahkan partisipasi tersebut kemudian berlanjut dengan masifnya melalui beragam penjualan merchandise yang dilakukan relawan "Teman Ahok" Salah satu tujuannya adalah untuk mengalang dana kampanye Basuki Thajaja Purnama dari publik. Langkah taktis relawan elektoral tersebut dapat diartikan sebagai upaya mendorong dan melibatkan publik secara partisipatoris dalam proses kampanye politik. Narasi tersebut kemudian dapat mengonfirmasi bahwa apa yang diungkapkan oleh relawan Teman Ahok bukanlah bagian dari gejala deparpolisasi yang selama ini dihembuskan oleh sebagian pihak. Apalagi kemudian ketiga partai lebih dulu mengambil langkah politis dengan mendukung Basuki Thajaja Purnama maju lewat jalur independen yakni Partai Golkar, Partai Nasdem dan Partai Hanura., sebelum kemudian diikuti oleh PDI-Perjuangan. Artinya langkah politis ini telah mementahkan isu deparpolisasi dan mengonfirmasi bahwa parpol dapat lebih aspiratif. Sebab ketiga partai ini tampak lebih berani 
menegakkan kembali filosofi demokrasi yang paling asasi, yakni memberikan kebebasan bagi setiap individu untuk ikut serta dalam kontestasi politik mekipun bukan melalui jalur parpol.

Akhirnya deskripsi atas besarnya atensi dan perhatian publik semakin menegaskan bahwa hingga saat ini relawan elektoral dapat menjadi salah satu saluran substitusi baru partai. Saluran substitusi ini dapat dilihat dari besarnya respon publik terhadap keinginan mendukung figur Basuki Thajaja Purnama maju melalui jalur independen. Meskipun pada akhirnya sosok Ahok harus memilih jalur parpol dikarenakan adanya upaya mengagalkan prasyarat calon independen. Akan tetapi gejala ini setidaknya telah membuktikan hingga saat ini bahwa publik lebih mempercayai kinerja relawan elektoral ketimbang kinerja partai. Apalagi kian hari publik kian rasional dan memahami buruknya kinerja partai terutama dalam hal kandidasi dan rekruitmen politik. Oleh sebab itu, kehadiran relawan Teman Ahok dalam kontestasi Pilkada DKI Jakarta yang dapat menjadi saluran substitusi baru partai harus dimaknai sebagai bentuk otokritik terhadap proses pelembagaan partai bukan justru sebaliknya. Dengan cacatan, pasca kontestasi peran relawan baik diranah intra dan ektsra parlementer yang diperankan oleh para relawan politik harus tetap mengedepankan

nilai-nilai kerelawanan (volunterisme). Pasalnya nilai-nilai tersebut dipercaya mengandung semangat revolusi mental, gotong royong serta dapat meminimalisir watak kekuasaan yang seringkali menjadi kultur politik Indonesia. Oleh sebab itu, dengan adanya pelembagaan aktivisme digital sebagai saluran komunikasi politik digital dapat menjadi alat kontrol bagi para relawan untuk saling mengawasi, baik dalam konteks pemerintahan termasuk bagi relawan politik yang tengah berada di intra parlementer.

\section{Kegagalan Partai dalam Rekruitmen Politik}

Kehadiran partai politik dalam ranah demokrasi menjadi sebuah hal yang mutlak. Partai bukan hanya menjadi pilar demokrasi, namun lebih dari itu dapat menjadi pengemban amanat publik dalam mewujudkan konsolidasi demokrasi. Ironisnya, pasca reformasi 1998 sengkarut korupsi-suap yang tengah menyelimuti partai politik menjadi penyebab utama menurunnya kepercayaan publik terhadap partai. Ulah segelintir elit populis dan oligarkis yang mencederai hati rakyat, menegaskan bahwa partai belum mampu melakukan proses pelembagaan partai dengan baik terutama dalam mengelola pembiayaan partai politik. Pembiayaan ini timbul dikarenakan sulitnya partai memenuhi kebutuhan operasional. 
Meskipun Undang-Undang (UU) Nomor 2 tahun 2008 tentang Partai Politik dan UU Nomor 2 Tahun 2011 tentang Perubahan atas UU Nomor 2 Tahun 2008 telah diatur soal sumber keuangan partai. Dimana, ada tiga sumber keuangan partai politik, yaitu, (1) iuran anggota partai bersangkutan. (2) sumbangan yang sah menurut hukum. (3) bantuan keuangan dari Anggaran Pendapatan Belanja Negara (APBN)/Anggaran Pendapatan Belanja Daerah (APBD). Tetapi realitanya, partai masih saja mengalami kesulitan mencari sumber pendanaan, apalagi jelang kontestasi politik elektoral.

Problem yang dihadapi partai terkait biaya operasional inilah yang turut mempengaruhi kegagalan partai dalam proses rekruitmen politik guna melahirkan kandidat politik pilihan rakyat. Sebab, partai lebih mendengar para oligarkis dan pemilik modal dalam menjalankan roda internal kepartaian. Jadi tidak heran bila kemudian kebijakan partai akan sangat paralel dengan keinginan pemilik modal. Akibatnya karakter partai kian menampilkan pola-pola yang jauh dari nilai-nilai demokratisasi. Bahkan, dalam proses rekruitmen politik baik diranah legislatif dan eksekutif partai masih saja menggunakan pola-pola politik transaksional yang banyak dipenuhi oleh tangan-tangan hegemoni para kaum oligarkis yang seringkali membajak partai politik.

Alhasil, kegagalan partai dalam proses rekruitmen politik ini akan membuat partai semakin sulit dalam melahirkan sosok kepemimpinan muda organik yang berasal dari akar rumput. Kepemimpinan organik dalam konteks ini yakni kepemimpinan yang berasal dari kader muda yang telah merangkak dari bawah sebagai sosok aktivis, ideolog partai, dan seringkali berjuang untuk kepentingan rakyat. Jika ditelisik ada beberapa penyebab mengapa partai seringkali mengalami kegagalan dalam proses kandidasi baik diranah legislatif maupun eksekutif diantaranya; Pertama, masih terlembaganya budaya patronase dan kuatnya cengkeraman figurfigur tua pada pucuk kepemimpinan partai. Sebut saja, di PDI-Perjuangan ada sosok Megawati, Aburizal Bakrie di Partai Golkar, Prabowo Subianto di Partai Gerindra, Surya Paloh di Partai Nasdem, Wiranto di Partai Hanura, dan Susilo Bambang Yudhoyono (SBY) di Partai Demokrat. Artinya, partai saat ini tidak lebih dari sekedar institusi pemuja para figur ketimbang ideologi. Akhirnya, elektabilitas partai kalah jauh ketimbang kandidat politiknya. Sosok kandidat politik akhirnya dianggap lebih penting ketimbang platform apalagi ideologi partai. Kedua, terjadinya krisis regenerasi dan 
kaderisasi yang dialami sebagian besar partai politik-terutama kader-kader muda. Hal ini erat kaitannya dengan pemberian kesempatan kepada kaum muda untuk membangun budaya meritokrasi di lingkungan internal kepartaian. Alhasil, kaum muda seakan sulit untuk mendapat ruang yang memadai dalam partai guna menyalurkan aspirasi politik masing-masing. Jika hal ini dibiarkan, partai akan sulit melahirkan kader-kader potensial dalam kontestasi elektoral maupun presidensial. Sebab, politisi dan figur tua dipastikan akan kembali memenuhi jagat kontestasi elektoral yang eksesnya dapat menggerus kepercayaan publik. Artinya kegagalan partai dalam proses kandidasi dapat menambah deret panjang kegagalan partai. Sebab partai sudah tidak lagi menjadikan ideologi dan platform sebagai sebuah garis perjuangan yang harus ditaati. Padahal platform akan menjadi pembimbing dan pengarah yang akan ditempuh partai dalam menunaikan janjinya kepada rakyat. Krisis kaderisasi dan regenerasi yang dialami sebagian besar partai saat ini terkait erat dengan minimnya pemberian kesempatan kepada kaum mudauntuk melakukan partisipasi aktif di lingkungan internal kepartaian masingmasing.

Jika gejala ini kian merebak maka kita akan sulit melahirkan partai inklusif yang mampu mengedepankan meritokrasi sekaligus berpengaruh bagi kemajuan negara-bangsa. Sebab, bila yang terlahir adalah partai ekstraktif atau elitis, maka akan melahirkan keadaan sebaliknya. Ironisnya partai politik seolah baru menyadari pentingnya regenerasi dan kaderisasi disaat akan menyusun calon anggota legislatif (caleg) jelang pelaksanaan kontestasi elektoral. Bahkan dalam Pilkada serentak 2015 banyak partai yang tidak bisa menawarkan kandidat politik yang kemudian melahirkan fenomena calon tunggal di beberapa daerah. Artinya kesalahan fatal tersebut lebih banyak disebabkan pengaruh budaya politik patronase, senioritas dan top-down yang menyebabkan mandeknya proses regenerasi dan kaderisasi dalam tubuh partai. Eksesnya partai belum mampu membangun institusinya sebagai rumah demokrasi. Rumah persemaian para kader-yang dipersiapkan guna melahirkan para calon pemimpin transformatif. Selain itu, kegagalan partai juga ditandai oleh semakin meluasnya gejala kesewenang-wenangan dalam sistem internal kepartaian. Banyak kebijakan strategis partai yang lebih berdasarkan pertimbangan kaum oligarkis, elitis, bahkan menegasikan aspirasi seluruh komponen kader terutama pada tataran aras lokal (grass-root). Padahal, sejatinya perbedaan pilihan politik dalam internal 
partai harus direspons dengan membuka dialog seluasluasnya dan partisipatif-bukan dengan jalan pemecatan. Oleh sebab itu, sudah saatnya dalam setiap proses rekruitmen politik partai harus berani mengedepankan mekanisme meritokrasi. Sebab langkah taktis ini dapat menjadi alternatif menyadarkan para elite partai-bahwa hal terpenting dalam suksesi kepemimpinan adalah melibatkan kaderkader muda, sebagai prasyarat utama melahirkan generasi baru partai. Akhirnya gejala kegagalan partai dalam rekruitmen politik harus segera dicegah melalui reformasi partai politik terutama pembenahan dan perbaikan manajemen internal kepartaian. Sebab jika tidak, hal ini akan semakin mengikis rasa afiliasitas, afeksitas, maupun afinitas terhadap realitas partai politikyang dapat membuat publik beralih pada saluran substitusi baru seperti relawan elektoral.

\section{Sekolah Partai Alternatif Reformasi Partai}

Rakyat yang mulai rasional dan cerdas cenderung melahirkan gejala apatis dan sinisme terhadap partai. Sinisme rakyat semakin mengemuka seiring dengan banyaknya elit partai yang terjebak korupsi politik menjadi bukti sikap disorientasi partai terhadap amanat rakyat. Itu mengapa kemudian rakyat menimbang hadir atau tidaknya sebuah partai, atau siapapun yang akan menjadi pemimpin, tidak ada artinya sama sekali bagi rakyat, apabila tidak mampu menciptakan perubahan yang lebih baik. Dalam nalar pemilih, partai hanya dikenal pintar mengumbar janji namun akan kesulitan mewujudkan janjinya. Keluhan rakyat bukan berarti merupakan perwujudan dari pola pikir yang negatif (negative thingking) atas eksistensi dan fungsi kepartaian dalam demokrasi modern. Keluhan ini justru merupakan bentuk kegelisahan rakyat yang hanya sekadar dijadikan kendaraan politik, alat kandidasi politik, dan sarana politik dagang sapi. Selama ini partai didirikan, hanya sebagai pertanda guna memperturutkan nafsu dalam kompetisi elektoral yang saban hari semakin ketat. Menjadi hal yang wajar jika semua partai mengklaim akan memperjuangkan kepentingan rakyat, namun dalam perkembangannya biasanya partai gagal mewujudkan impian tersebut. Partai bahkan sering dianggap manipulatif, ibarat sekedar menginjak kepala rakyat untuk dijadikan tangga meraih kekuasaan dan membuat kebijakan atas nama rakyat yang sejatinya merugikan rakyat.

Melihat gelagat tersebut reformasi partai politik mutlak diperlukan guna mendorong kelahiran partai modern dengan model pelembagaan yang lebih sistematis. Oleh sebab itu perlu adanya perbaikan institusi partai 
politik, baik pada aspek organisasi dan manajemen, pendanaan partai, rekrutmen kader-serta pembangunan institusi dengan platform kebijakan yang berpihak pada rakyat. Sebab, menurut The International Institute for Democracy and Electoral dalam laporan tahunan edisi 2011, sejatinya partai harus mampu menjadi alat representasi publik dengan menyediakan beragam pilihan-pilihan politik, termasuk ikut serta memberikan pilihan calon kepala daerah. Namun, realitasnya, partai justru semakin mengalami disorientasi terutama dalam mengolah sistem "reproduksi" kader partai.

Fenomena kegagalan partai yang mengemuka dan melahirkan saluran substitusi baru seperti relawan elektoral haruslah disadari sebagai gagasan untuk segera membenahi partai. Urgensi dari reformasi partai ditujukan untuk membangun pelembagaan kaderisasi yang baik, sehingga kedepan partai dapat tetap menawarkan beragam calon-calon transformatif dalam ritus kontestasi politik nasional dan lokal. Salah satu langkah reformasi partai yang patut ditekankan saat ini adalah mengulirkan ide sekolah partai. Itu mengapa, ketika Partai Demokrasi Indonesia Perjuangan (PDI-Perjuangan) mengagas pendirian "sekolah partai" publik memberikan apresiasi yang sangat positif. Pasalnya, publik telah jenuh dengan ulah partai yang semakin memperlihatkan tingkat arogansinya terutama ihwal proses rekrutmen politik. Apalagi proses rekrutmen politik baik legislatif dan eksekutif, kian tertutup dari publik. Bahkan, akses media massa, masyarakat sipil dan publik sebagai stakeholder utama, diminimalisir sedini mungkin. Padahal, publik berhak mengetahui mekanisme rekrutmen politik, karena partai sejatinya adalah milik publik. Apalagi, keberadaan partai pada dasarnya karena ada kebutuhan untuk mewadahi aspirasi kelompok dalam masyarakat yang berbeda satu sama lain, seperti ideologi, demografi, dan berbagai perihal lainnya.

Artinya, terobosan sekolah partai dapat menjadi prototipe sekolah calon pemimpin yang lebih berorientasi untuk menyemai lahirnya kader partai yang melayani rakyat dan bukan dilayani. Adapun beberapa urgensi sekolah partai diantaranya; Pertama, dapat menjadi alternatif mengembangkan sayap kaderisasi partai dengan model yang sistemik, terukur dan modern. Alhasil, program kaderisasi akan semakin kreatif dan dapat menyesuaikan kondisi daerah masingmasing. Kedua, sebagai bentuk pernyataan yang tegas bahwa partai bukanlah organisasi yang hanya berwatak transaksional, pragmatis dan hanya menekankan politik uang dalam meraih kemenangan dalam 
ritus kontestasi politik. Itu mengapa, dalam kegiatan sekolah partai yang pernah di gelar PDI Perjuangan, banyak dibekali oleh pengetahuan seputar komunikasi politik, kampanye kreatif, kampanye di media sosial, penyusunan politik anggaran, internalisasi revolusi mental, hingga bagaimana membangun semangat gotong royong untuk meraih kemenangan. Ketiga, dapat menjadi wahana pembelajaran dan pendidikan politik bagi publik. Sebab selama ini model pendidikan politik terkesan elitis dan tidak tepat pada sasaran yang dibidik. Alhasil, program edukasi dan pendidikan politik yang digulirkan oleh partai politik lebih bias kepentingan dan hanya menghabiskan anggaran partai. Keempat, sekolah partai dapat menjadi wahana bagi upaya membangun diskursus perihal gaya kepemimpinan transformatif yang mau mendengar suara rakyat. Sehingga akan terbentuk sinergitas antara kandidat politik dengan visi dan misi parpol. Artinya, benturan kebijakan parpol dengan kader yang diusung dapat dihindari. Urgensi sekolah partai juga dikaitkan dengan adanya perubahan perilaku pemilih Indonesia yang cenderung lebih dipengaruhi elektabilitas kandidat politik. Pemilih lebih memiliki kecenderungan memilih kandidat politik, bukan karena daya tarik terhadap partai dan programnya, melainkan lebih pada ketertarikan pada figur yang diusung.

Fenomena ini akhirnya seringkali mengubah gelanggang elektoral menjadi kontestasi antar figur politik. Eksesnya, partai semakin dilematis, karena perannya sebagai mesin pemenangan semakin tergerus oleh peran dan kreativitas kandidat politik yang lebih dominan dalam upaya menarik atensi publik termasuk dengan kehadiran relawan elektoral. Gejolak inilah yang harus segera disikapi dan diperhatikan oleh partai politik sehingga krisis kader seperti yang terjadi pada Pilkada DKI Jakarta 2017 tidak terjadi lagi. Meski pada akhirnya Ahok membatalkan pencalonan melalui jalur perseorangan dan kembali maju melalui jalur partai politik. Hal inilah yang menegaskan bahwa partai politik masih menjadi tumpuan dalam proses kandidasi politik. Dengan demikian, langkah taktis dengan mengulirkan sekolah partai, bisa menjadi salah satu alternatif reformasi partai politik dalam upaya guna melahirkan kandidat politik pilihan rakyat.

\section{E. SIMPULAN DAN SARAN \\ 1. Simpulan}

Akumulasi kekecewaan publik atas laku partai politik terkait rekruitmen politik yang seringkali dimanipulasi hingga menguatnya praktik klientalistik dalam internal kepartaian-pada akhirnya dapat menciptakan 
sentimen anti-partai. Sebab publik seringkali menilai partai susah mendengar suara rakyat, karena besarnya dominasi kaum oligarkis dalam proses rekrutimen politik. Bahkan menurut studi Dhakide (2014) dilihat dari sudut mana pun - dari bawah dari atas - semua menunjukkan bahwa partaipartai sudah bukan yang dulu lagi, power and power sharing menjadi citacita dan bukan tuntutan tinggi ideologis tetapi transaksional. Gerak pergeseran partai menuju keadaan sekarang sudah tampak pada Pemilu 2004 dengan gejala semakin meningkat pada Pemilu 2009. Perlahan namun pasti partai-partai sedang berkembang ke arah yang berbeda dari yang pernah dikenal. Partai tipe pergerakan sudah lama hilang, meski sisa-sisa terakhir masih bisa dilihat menjelang pemilihan umum 1999.

Jikalau hal ini terus bergulir dapat sejalan dengan ungkapan Daalder (dalam Pamungkas, 2011), sebagai pertanda the redundancy of party yang menunjukkan bahwa rakyat Indonesia tidak lagi mempercayai partai politik sebagai artikulator kepentingan mereka. Artinya, rakyat lebih mempercayai institusi-institusi demokrasi lainnya sebagai artikulator kepentingan ketimbang partai politik seperti relawan Teman Ahok. Itu mengapa, dalam kontestasi Pilkada DKI Jakarta relawan Teman Ahok mampu menjadi saluran substitusi baru partai. Hal itu disebabkan oleh kekecewaan publik terhadap partai semakin diperparah dengan tidak berjalannya proses rekruitmen politik terutama dalam melahirkan kandidat politik pilihan rakyat. Artinya, partai politik belum juga mampu membangun menjadi sebuah institusi demokrasi dan rumah persemaian para kader-yang ditujukan dan dipersiapkan guna melahirkan para calon pemimpin transformatif. Jika hal ini dibiarkan, pelan tapi pasti partai politik akan mengalami krisis kader potensial, terutama kaderkader muda. Oleh sebab itu dengan kehadirnya relawan Teman Ahok yang telah mengedepankan kinerja yang sistematis--- setidaknya dapat dijadikan saluran subsitusi baru serta wahana otokritik perihal sejauh mana parpol telah mampu mengedepankan fungsi intermediasi antara kepentingan publik dengan kebijakan parpol.

\section{Saran}

Akhirnya, langkah taktis untuk mereformasi partai yakni dengan mendorong pelembagaan sekolah partai. Dengan kandungan materi dari sekolah partai dapat menjadi alternatif partai untuk kembali mengedepankan telah proses rekruitmen politik yang berpijak pada mekanisme meritokrasi. Artinya, jikalau gerakan sekolah partai dapat dijadikan menu utama oleh semua partai di Indonesia, maka hal ini dapat menjadi salah satu alternatif 
Vol.1 No.1 Juni 2019

guna mempertahankan eksistensi partai dari krisis kader dan regenerasi.

\section{DAFTAR PUSTAKA}

Arianto, Bambang. (2014). Fenomena Relawan Politik Dalam Kontestasi Presidensial 2014. Jurnal Ilmu Sosial dan Ilmu Politik. Vol. 18, No. 2 Edisi November. hlm 147.

Kampanye Kreatif dalam Kontestasi Presidensial 2014. Jurnal Ilmu Sosial dan Ilmu Politik. Vol. 19, No. 1 Edisi Juli.

$\begin{array}{lrr}\text { Peran } & \text { Relawan Politik } \\ \text { Pasca } & \text { Kontestasi } \\ \text { Presidensial 2014. }\end{array}$

Kampanye Politik Digital dalam Kontestasi Presidensial 2014; studi Demokreatif dan JASMEV 2014. Thesis tidak dipublikasikan. S2 Departemen Politik dan Pemerintahan UGM.

Andriadi, Fayakhun. (2016). Demokrasi di Tangan Netizen, Tantangan dan Prospek. RMBooks Jakarta.

Arya, Budi. (2013). Membongkar Veto Player dalam Politik Kepartaian Indonesia Menuju Pemilu 2014. Jurnal Ilmu Sosial dan Ilmu Politik. Vol. 17, No. 1 Edisi Juli. hlm 52
Asril, Asrinaldi. (2015). Pilkada dan Uang Survei Kepala Daerah. Harian Kompas. Edisi 4 Juni

Bhakti, Ikrar Nusa. (2016). Ahok dan Tuduhan Deparpolisasi. Harian Media Indonesia. Edisi 14 Maret

Caton, Matthias. (1999). Effective Party Assistance : Stronger Parties fot better Democracy. Cambridge USA.

Dhakidae, Daniel. (2014). Partai Politik di Persimpangan Jalan. (online) http://www.prismajurnal.c om/uploads

Lsurvei partai politik.pdf. $\underline{\mathrm{hlm} 96 .}$.

Jati, Wasisto Raharjo. (2016). Politik Generasi Y. Harian Kompas. Edisi 28 Mei (2016). Masa Depan demokrasi Digital. Harian Kompas. Edisi 23 September.

Kurniawan, Hamdan (2011). Melawan Partai Politik "Strategi Calon Perseorangan dalam Merebut Suara di Pemilukada Slemana tahun 2010". Thesis tidak dipublikasikan. S2 Departemen Politik dan Pemerintahan UGM.

Minanto, Ali. (2010). Fashionable democracy; banalitas iklan politik di ruang publik. Jurnal komunikator UMY. 
Vol.1 No.1 Juni 2019

Volume 2 Edisi No 2

November. hlm 188

Moleong, Lexy J. (2005). Metode

Penelitian Kualitatif.

Bandung: PT. Remaja

Rosdakarya.

Pamungkas, Sigit. Partai Politik,

Teori dan praktik di

Indonesia. Yogyakarta.

Institute for Democracy and

Welfarism (IDW), 2011.

Sarwono, Sarlito Wirawan.

Blusukan. (2014). Harian

Koran Sindo, Edisi 6 Juli

Utomo, Wisnu Prasetya. (2013).

Menimbang Media Sosial

dalam Marketing Politik di

Indonesia: Belajar dari

Jokowi-Ahok di Pilkada DKI

Jakarta 2012. Jurnal Ilmu

Sosial dan Ilmu Politik. Vol.

17, No. 1 Edisi Juli. hlm 76

Widodo, Joko. (2014). Revolusi

Mental. Harian Kompas,

Edisi 10 Mei

\section{Internet}

cnnindonesia.com. (2015). KTP

Dukungan Ahok Lampaui

Perolehan Suara Parpol.

(Online).http://www.cnnin

donesia.com

/politik/20160224135931-

32- 113178/ktp-dukungan-

ahok-lampauiperolehan-

suara-parpol/, diakses 25

Oktober 2016

kompas.com. (2016). Menurut

Ahok, Calon Independen

Akan Hilang jika Parpol

Profesional. (Online).

http://nasional.kompas.co

$\mathrm{m} / \mathrm{read} / 201$
6/03/10/14043651/Menur

ut.Ahok.Cal

on.Independen.Akan.Hilang.

jika.Parpol. Profesional.

diakses 7 Oktober 2016

pukul 15.00

(2016). Teman Ahok

Mei 2016 Ahok Deklarasi

sebagai Calon Independen.

(Online).

http://megapolitan.kompas

.com/read/

2016/01/25/19365711/Te man.Ahok.

Mei.2016.Ahok.Deklarasi.se bagai.Calon. Independen, diakses 7 Oktober 2016, pukul 16.00

(2016). Pengumpul

Data KTP "Teman Ahok"

Dibayar Rp 500.000 Setiap

Dapat 140 Data. (Online). http://megapolitan.kompas .com/read/

2016/06/22/13210871/pe

ngumpul.kt

p.teman.ahok.dibayar.rp.50

0.000.setiap .dapat.140.ktp,

diakses 10 November 2016

pukul 10.00. 2016). PDI-P Adakan

Sekolah untuk Calon Kepala Daerah Pilkada Serentak 2017.

(Online).http://nasional.ko mpas.com $/ \mathrm{r}$

ead/2016/08/30/1740146

1/pdip.adak

an.sekolah.untuk.calon.kepa

la.daerah.pi

lkada.serentak.2017, 
diakses 9 November 2016, pukul 07.00

lipi.go.id. (2016). Membangun Kesadaran Politik Publik. (Online). http://lipi.go.id/lipimedia/ single/- membangunkesadaranpolitikpublik/12378, diakses 10 November 2016. merdeka.com. (2016). Melatih relawan militan penangkal fitnah. (Online). https://www.merdeka.com /khas/melatih-relawanmilitan-penangkal-fitnahtim-medsos-cagub-dki2017.html, diakses 10 November 2016.

---------- 2014). Hasil rekap Teman Ahok, jumlah KTP yang terverifikasi 1.000.264. (Online). https://www.merdeka.com /politik/has il-rekapteman-ahok-jumlah-ktpyangterverifikasi1000264.html, diakses 10 Oktober 2016.

organix-digital.com.

Definisi dan Fungsi Hashtag pada Media Sosial. (Online). http://organixdigital.com/b $\log / \mathrm{read} /$ definisidanfungsi-hashtag-padasosial-media, diakses 8 November 2016.

tempo.co. (2015). Gagal Maju Pilkada, Mantan Jaksa Ini Akan Gugat Gerindra. (online). https://m.tempo.co/read/n ews/2015/

08/01/078688274/gagalmajupilkada-mantan-jaksaini-akan-gugatgerindra, diakses 20 Oktober 2016 (2016). Relawan Garin Nugroho Menyerah Tak Ikut Pilkada Yogyakarta (Online). https://nasional.tempo.co/ $\mathrm{read} /$ news/ 2016/07/21/058789395/r elawangarin-nugrohomenyerah-tak-ikutpilkadayogyakarta, diakses 26 Oktober 2016. --(2016). Siapa Saja Pendiri Teman Ahok? Inilah Profil Mereka. (Online). https://metro.tempo.co/re ad/753591/ siapa-sajapendiri-teman-ahokinilahprofil-mereka, diakses 26 Oktober 2016.

Tribunnews.com (2016). Kisah di Balik Berdirinya Teman Ahok. (Online). http://www.tribunnews.co $\mathrm{m} /$ metropol itan/2016/05/29/kisah-dibalikberdirinya-temanahok?page $=2$, diakses 2 November 2016.

Twitter.com. (2016). @temanahok.(Online). https://twitter.com/teman Ahok, diakses 5 Oktober 2016.

\section{Narasumber}

Singgih Widiyastono, pendiri relawan Teman Ahok, 5 
Vol.1 No.1 Juni 2019

Desember 2017 via Twitter, pukul 08.00

Siti Murtika, relawan JASMEV 2017, 10 Agustus 2016 via

Whatsapps pukul 21.00.

Elfrida Manurung, warga DKI

Jakarta Utara, 10 Agustus 2016 via Whatsapp pukul

17.00 . 